University of Michigan Law School

University of Michigan Law School Scholarship Repository

\title{
Partnership Entity and Tenancy in Partnership: The Struggle for a Definition
}

Joseph H. Drake

University of Michigan Law School

Available at: https://repository.law.umich.edu/articles/1136

Follow this and additional works at: https://repository.law.umich.edu/articles

Part of the Business Organizations Law Commons, Comparative and Foreign Law Commons, and the Legal History Commons

\section{Recommended Citation}

Drake, Joseph H. "Partnership Entity and Tenancy in Partnership: The Struggle for a Definition." Mich. L. Rev. 15 (1917): 609-30.

This Article is brought to you for free and open access by the Faculty Scholarship at University of Michigan Law School Scholarship Repository. It has been accepted for inclusion in Articles by an authorized administrator of University of Michigan Law School Scholarship Repository. For more information, please contact mlaw.repository@umich.edu. 


\section{MICHIGAN}

\section{LAW REVIEW}

\begin{tabular}{lll}
\hline \hline VoI. XV. & JUNE, I9I7 & No. 8. \\
\hline
\end{tabular}

\section{PARTNERSHIP ENTITY AND TENANCY IN PARTNER- SHIP: THE STRUGGLE FOR A DEFINITION.}

66 D ARTNERSHIP is a legal entity formed by the association of two or more persons." 1 This definition of a partnership as a person or entity represents what may be characterized as a generally accepted theory among American jurists at the time of its publication in I893. But a later definition says: "A partnership is an association of two more persons." "A partner is co-owner with his partners of specific partnership property holding as a tenant in partnership." The second definition shows that the Commissioners on Uniform State Laws have rejected the entity theory and coined a new term to describe partnership holding.

At the beginning of every discussion as to the nature of partnership $^{3}$ one is likely to find the dictum of Sir GEORGE JESSEL, Master of Rolls. In speaking of agency as a test of the existence of a partnership in law without agreement of the parties he says: "You cannot grasp the notion of agency, properly speaking, unless you grasp the notion of the existence of the firm as an entity separate from the existence of the partners; a notion which was well grasped by the old Roman lawyers, and which was partly understood in the courts of equity before it was part of the whole law of the land as it is now. But when you get that idea clearly, you will see at once what sort of agency it is. It is the one person acting on behalf of the firm. He does not act as agent, in the ordinary sense of the word, for the others so as to bind the others; he acts on be-

\footnotetext{
1 Parsons, On Partnership, 4th ed., revised by Beale ( 1893 ), p. I.

2 The Uniform Partnership Act, [cited hereafter as U. P. A.]. Adopted by The Conference of the Commissioners on Uniform State I,aws, October 14, 1914. Sec. 6 (x) and 25 ( 1 ).

- Parsons, On Partnership, 4th ed., revised by Beale, p. 3 ; Burdick, On Partnership, 2nd ed., p. 177; Gilmore, On Partnership, p. 273; 28 Harv. I. Rev. 766; 57 Cent. Law Jour. 343.
} 
half of the firm of which they are members; and as he binds the firm and acts on the part of the firm, he is properly treated as the agent of the firm. If you cannot grasp the notion of a separate entity for the firm then you are reduced to this, that inasmuch as he acts partly for himself and partly for the others, to the extent that he acts for the others he must be an agent, and in that way you get him to be an agent for the other partners, but only in this way, because you insist upon ignoring the existence of the firm as a separate entity." This dictum was uttered at a time when the modern theory of partnership entity was well developed both in this country and in England, in the writings of scientific jurists and in the dicta of courts, though not to any considerable extent in the decisions themselves. It is usually assumed to be an authority for the doctrine that the partnership is a legal person and not an association of natural persons; but a careful analysis of it will show that this conclusion is scarcely warranted from the words themselves. In fact the latter part of the citation given above seem to indicate that even the learned Master of Rolls himself might possibly have admitted a different interpretation.

The concept of a unit entity in partnership is identical with the idea of the juristic person in a corporate body, that is, the natural persons, $\mathrm{A}, \mathrm{B}$ and $\mathrm{C}$ become by their association an $\mathrm{X}$ persona which enters into legal relations with other personae through the agency of $\mathrm{A}, \mathrm{B}$ or $\mathrm{C}$. It is evident that this is the concept in the mind of JESSEL, and his dictum may therefore be properly cited as authority for the entity theory. But at the end of his statement he suggests another solution-though only to condemn it-and it is this solution which an overwhelming majority of the courts have implicitly accepted, though no court, so far as I know, has explicitly stated the reason for acceptance. The two concepts are so closely related that in the discussion of them in the cases there is frequently an unconscious transition from one to the other, with the consequent confusion in the conclusion that results from arguing from a premise that has different meanings which may be easily interchanged. The associative theory of partnership is implicitly contained in JESSEL's statement, "that inasmuch as he acts partly for himself and partly for the others, to the extent that he acts for the others he must be an agent." $\mathrm{A}, \mathrm{B}$ and $\mathrm{C}$ may of course be thought of as constituting a unit entity, $X$, external to the natural persons, who act as its agents but what we do actually think of in a partnership is that each partner acts for the others and for himself. It should be noted also that this latter

- Pooley v. Driver, 5 Ch. Div. 458, (1876). 
concept may be thought of as an entity, but it certainly is a very different concept from that of the juristic person. It might well be characterized as a composite entity but it is not the unit entity of the juristic person. It will be found on examination of the sources that only the composite entity existed in the old Roman law of partnership, that the composite entity was identified with the unit entity in the mediaeval law merchant, but that the. attempt to amalgamate the former with the latter in English and American courts has not yet been crowned with success, and if our new UNIFORM PARTNERSHIP ACT should be generally adopted in American jurisdictions the tendency toward their amalgamation will be delayed, if not permanently checked. Whether such an effect would be desirable or not will be considered later.

The Commissioners on Uniform State Laws who codified the UNIFORM PARTNERSHIP Acr seem to have tried to avoid the danger of too rigid a definition of partnership by describing it as an "association" and calling its members "tenants in partnership," giving us thus a new form of tenure, though apparently one not invented by the Commissioners themselves. Back of this formulation by the codifiers there is a long and interesting discussion, and as much of the trouble seems to have been caused by a confusion of terminology and an attempt to force new -wine into old bottles with the usual unsatisfactory consequences, it seems that a re-examination of the sources and a careful study of the historical development of the two conflicting ideas may clarify our thinking and aid in the solution of the very practical question as to whether or not our legislatures should adopt the UNIFORM PARTNERSHIP ACT as the best statement of our present law on the subject. .

As soon as several men begin to hold property together or act together in some common enterprise we are at once confronted with a number of perplexing questions as to their legal relations to each other, to other persons or groups and to the property with which they may. deal. These problems are as old as society itself, and it is not surprising that the advocates of either side of the dispute have sought for assistance in the three main sources of our partnership law; namely; the. Roman Law, the Law Merchant of medixval times and the Commion Law. The various associative relations are arranged in a graduated hierarchy of groups. At the bottom is the least complicated form. It is simply a common holding. This is the

- Entity is defined by the Century Dictionary as, An independent ens. Ens, which is the present participle of the Latin esse, is defined as that which in any sense is. For Dean Lewis's definition of an entity, see post, note 84 .

- For the origin of this institution, see post, p. 618 , note $3 \mathrm{r}$. 
communio or codominium of the Roman law and in English law appears as a joint tenancy with four unities, a coparcenary with three unities or a tenancy in common with a single unity. The fundamental characteristic of these is that each is a passive right. It is a group-holding, a tenure. A, B and C are thought of simply as co-holders. This group hereafter will be referred to as the tenure concept, and may be thought of objectively as $\mathrm{A}, \mathrm{B}$ and $\mathrm{C}$ included within a circle.

The next higher group has active as well as passive rights; i. e., there is not only a group tenure but a group activity. An example of this both in Roman and English law is a co-principalship, in which an agent acts for joint principals. ${ }^{7}$ Just above this is the societas of the Roman Law, the partnership of English law. The subject matter of this paper is the intrinsic-possibly one might say the metaphysical-character of this institution, if, to paraphrase THomAsIUS, a legalist may dare to insert his sickle into the field of dread metaphysics. All systems of law agree that partnership usually includes the basic element of tenure. $\mathrm{A}, \mathrm{B}$ and $\mathrm{C}$ hold property together. But beside this passive right they have active functions. They deal with the property, with each other and with other persons and groups. This partnership group will hereafter be referred to as the firm concept. It may be thought of objectively as $A, B$ and $\mathrm{C}$ at the apices of a triangle whose sides represent the relation of mutual principalship and agency, with the triangle inclosed in a circle to represent the common tenure. ${ }^{8}$

Outside of these groups and differing from them not only in degree but in kind is the institution known as the juristic person or corporation. Whereas in the partnership group we have the concept of $\mathrm{A}, \mathrm{B}$ and $\mathrm{C}$ holding property together and each acting for himself and for the others in their dealings; in the corporation we have the highly abstract concept of $\mathrm{A}, \mathrm{B}$ and $\mathrm{C}$ acting as agents for a persona, $\mathrm{X}$, extrinsic to themselves. This extrinsic persona is a unit entity. It existed in the classical Roman law but according to the generally

TThis grouping is of no importance for us in the present discussion, although it is shown by arguments in modern cases that the courts still have difficulty in distingtishing joint agency from the mutual principalship and agency, of a partnership. $C$. the case of French v. Styring, 2 C. B. R. (N. S.) 355 (1857), and the discussion in Beecher v. Bush, 45 Mich. 200.

s Closely allied to the partnership grouping is the joint trust, in which $A, B$ and $C$ hold property jointly, to be devoted to a specific purpose; e. g., the benefit of some other party or parties. This associative activity is said by Maitland, in his Translator's Introduction to Gierke's Political Theories of the Middle Ages, p. xxxiii, to go back to the Lex Salica where the "trustis is a group of comrades." It has however attained its highest development not in Continental but in English law. It however, like the co-agency, need not be considered here. 
accepted theory it was recognized as a legal institution at a comparatively late period and then only in the law of corporations. Objectively it may be thought of as an $\mathrm{X}$ persona extrinsic to the natural persons $\mathrm{A}, \mathrm{B}$ and $\mathrm{C}$, who act as its agents. This corporate grouping will hereinafter be referred to as the unit entity. An entity in this sense does not exist in the classical Roman law of partnership. This is admitted even by the advocates of the entity theory in the modern law of partnership. ${ }^{9}$ Whether this entity is a fiction or a real existence is not pertinent to this discussion. We are concerned only with its characteristic as an entity extrinsic to the natural persons. It is also of no moment as to whether this concept of a juristic person came into the classical Roman law early or late. It is only to be noted that it does not exist at all in the partnership law of the classical period.

There has always been in all systems of law a fairly clear idea of the nature of common tenure, i. e., the mere associative holding of property. It is only when we come to the associative activities that .our legal thinking begins to get hazy. The two concepts that have become blurred in the nineteenth century are, on the one hand, the associative activity of the partnership group (the firm concept), and on the other, the activity of the juristic person through the agency of the individuals who are extrinsic to the juristic persona (the unit entity). It should be borne in mind that either the associative activity of the group or the juristic person may be called an "entity," in the sense that each is an actually existent concept, but the term is usually applied only to the entity which is also a unity, i. e., the juristic person. This is the sole use when we come to talk of corporations, and when we are dealing with partnership it seems that much of our confusion arises from the old error of formal logic, namely, reasoning from a divided middle."

\section{PARTNERSHIP ENTITY IN CLASSICAPL ROMAN LAW.}

ÚLPIAN says: "There must be a partnership, if one would bring an action pro socio, for group tenure without partnership will not warrant the action." 10 He here recognizes the group tenure and makes plain the distinction between group tenure and group tenure plus group activity; the last of which constitutes a partnership. But at an earlier place in the Drgest,"1 under the title "Communi Dividundo," Paulus confuses the simple group tenure with the partnership

98 Harv. L. Rev. 763 and Note 7 .

10 Ut sit pro socio actio. societatem intercedere oportet; nec enim sufficit rem esse communem, nisi societas intercedit. Digest 17. 2. $4 \mathrm{I}$.

${ }^{11} \mathrm{Si}$ inter socios convenisset ne intra ** certum tempus societas divideretur. Digest, 10. 3. 14. 3. 
holding. He talks about a division of the societas by the socii in a discussion of a severance of the jointure of tenants. There is the same confusing use by the Roman jurists of the term socius. Occasionally we find it with the meaning of joint tenant, ${ }^{12}$ though it is regularly used meaning partner. There seems to be no attempt at defining societas in the DIGEST, either because the classical jurists did not feel the need of it or, as seems more probable, they felt that they were unable to formulate an abstract definition. ${ }^{13}$

There is then in the classical Roman law a well defined concept of the common holding, communio, codominium, existing either without qualification, i. e., equivalent to a common law tenure, or in connection with societas in which, in addition to a common holding, we have the associative activity. There seems, however, to be no intimation in the Roman sources that this associative activity is that of a juristic person. Therefore Sir GEORGE JESSEL's statement in Pooley v. Driver that the "notion [of an entity] was well grasped by the Roman lawyers" is either wrong or the "entity" referred to is not the unity of a juristic person but an entity thought of as a composite activity. JESSEI, seems to see this dimly, as is evident from the latter part of his statement cited at the beginning of this paper. But although JESSEL does impliedly recognize the composite entity in the associative activity of a partnership, those who cite his dictum stress.only the earlier part of it, which speaks of a unit entity such as is found in the juristic person. This entity as a unity exists in the classical Roman law but it seems to have developed at a late period and then not in the law of partnership but in connection with the universitas, our modern corporate idea. Even here the concept of this entity as a fictitious person and a unity in our modern sense was never fully grasped by the old Roman lawyers. $^{14}$ The partnership in the old Roman law is a group having a common tenure together with composite activities of the members, and there seems to be no tendency to assimilate it to the juristic person, the unit entity of the corporation.

10 $\mathrm{Si}$ fundus communis nobis sit * * nam et si pars socio tradita fuisset. Digest, 10, 3. 6. 8. Salkowski, Roman Private Law, \$124, suggests that partnership was developed out of the common tenure in the consortium tenure of a family. Cf. Pound in 24 Harv. L. Rev. 603, and Crane in 28 Harv. L. Rev. 764.

${ }^{2}$ Omnis definitio in jure civili periculosa est. Digest, 50. I7. 202.

14 "The admission must be made that there is no text which directly calls the universitas a 'persona' and still less any that calls' it 'persona ficta." Maitland, Translator's Introduction to Gierke's Political Theories of the Middle Ages, p. XVIII. Maitland, following Gierke, attributes the fiction theory to Pope Innocent IV, who came to the papal throne in r243. See Gierke, Genossenschaftsrecht III, 279. Cf. Maitland, 1. c. Iruckily for our purpose we do not have to pay any attention to the question as to whether this entity is "fictitious" or "real" because most of the American cases ignore Gierke's theory. 
In some of the modern discussions of the origin of corporations in early laws there is an amalgamation of certain characteristics of the composite entity of the group and the unit entity of the juristic person. HEARN says "the oldest artificial person seems to have been the family."1s The Romans personified Roma at a very early period $^{16}$ and to the early Romans the gens was as real an existence as the individual members of it. ${ }^{17}$ We therefore find BLACKSTONE saying that "the honor of inventing these political constitutions [corporations] entirely belongs to the Romans. They were introduced, as PluTARCH says, by Numa."18 This statement of Blackstone may, however, be catalogued along with the rest of his historical inventions, the stock theory being that, "the conception of a juristic person was not introduced into the private law of Rome till the time of the Empire."19 It seems probable that the familia and the gens, while they had a real existence as a concept in the minds of primitive Romans, were a group rather than a unit entity or as personifications they had rather a religious ${ }^{20}$ than a legal signification and apparently never got beyond that stage. The personification of the city Roma is to be compared with that of Divus Augustus rather than with the juristic person, the imperial fiscus.

We find in mediaeval law an interesting survival of the old family idea carried over into the law of the gilds, ${ }^{21}$ the members of which were thought of as brothers or sisters in a gild family. These family groups have however the characteristics of archaic law. They belong to the early period of Roman law and to the naive period of mediaeval law. The conception of them is hazy and undifferentiated and in this respect they differ from the sharply defined concept of the unit entity of the juristic person which belongs to the later period of legal thinking. Both concepts are abstractions but whereas the first one is simply abstract and vague, the other, is abstracted and more clearly defined.

\footnotetext{
15. Fearn, The Aryan Household, p. 64.

18 "Roma was in reality the genius of the city of Rome, and was worshipped as such from eariy times." Smith, Dictionary of Greek and Roman Biography arid Mythology.

17 "Each gens had religious ceremonies to perform." * " "It was a duty to perpetuate this worship from generation to generation." * " "The gods of the gensDei gentiles-protected no other gens." Fustel de Coulangès, The Ancient City, p. 135. "Commentaries $\mathrm{I}, 48$.

19 Cf. Sohm, Institutes, p. 189 .

? "The best established and most prominent characteristic of the gens is, that, like the family it had a worship." Fustel de Coulanges, op. cit., p. I39.

${ }^{4}$ Scott's, Joint Stock Companies to I720, p. 3. "Early gilds or fellowships were marked by the analogy of the family. The members were usually described as 'brethren' and 'sistern.' Whether there was any conscious reference to an-artificial family is not certain."
} 


\section{THE ENTITY THEORY IN MIEDIAEVAL LAW.}

During the Middle Ages the law of partnership developed on the Continent along two distinct lines. From the eleventh century, the revived civil law of Rome was studied at Bologna, Ravenna and other Italian cities, and this revived Roman law was afterwards received by most of the Continental states as the basis of their law. But from the tenth century, alongside of the common law of the several states, there began to develop in the fairs and markets of the towns a body of law known later as the Law Merchant. Questions involving partners were decided in the courts of the fairs and markets, and partnership theory was discussed by the Glossators and Commentators of the civil law. In this way the principles of the practical Law Merchant tended to become absorbed in the civil law of the time, very much as the rules of merchants were carried over into the common law of England by the ruling of the judges in the English courts, particularly in the court of Lord MANSFIEID during his long term as Chief Justice. ${ }^{22}$

BARTOLUS, the great Italian commentator on the revived Roman law, says that it was customary throughout almost all of Italy in his time (fourteenth century) for one partner to use his own name and the class name of his associates as the title of the firm; $i$. e., Titius et socii. ${ }^{23}$ BRISSAUD thinks that such a name given to a partnership carries with it the idea of a distinct personality. ${ }^{2 *}$ Whether this conclusion of BRISSAUD necessarily follows from his premise may certainly be questioned. The collective name may be applied to the associative activity without any thought of a unit entity. The name is that of a composite entity, $\mathrm{A}, \mathrm{B}$ and $\mathrm{C}$; holding together and acting conjointly, and this composite picture of $\mathrm{A}, \mathrm{B}$ and $\mathrm{C}$ is not a photograph of $X$. Nevertheless, there seems to be no reason to doubt that within a century or two after BARToLus the mediaeval lawyers did make this transition, and a partnership becomes from this time on an entity of the unit type. Scaccia, a writer on the Law Merchant in the sixteenth century, says: Aliud est corpus unius societatis, et aliud est quilibet socius ipsius societatis. ${ }^{25}$ It is evident that SCACCIA here has in mind the concept of a partnership existing as a

22 See Burdick: What Is a Law Merchant? Select Essays in AngIo-American I,aw, Vol. III, p. 45 .

22 Goldschmidt's, Handelsrecht, p. 276, note 137. Cited by Mitchell, The Iaw Merchant; p. 130, note 2.

${ }^{24}$ History of Frenci Private Law, Vol. III, p. 556, of the Continental L,egal History Series.

$2 \approx$ De Commerciis et Canbio, \$r, quaest. I, 450. Cf. Holdsworth's, The Early History of Commercial Societies, 38 Juridicial Review, p. 312, from which the last three references are taken. 
juristic person extrinsic to the partners themself. "The corpus of a partnership," he says, "is one thing but any member of the same partnership is another." The group function of. the partners acting together has become identified with the juristic person. The partnership is no longer an association, it is an entity and that entity is a unity and not a composite activity. It is worthy of note that if the word aniversitatis were substituted for societatis in the above citation, we should have exactly the same connotation of a partnership entity that ULPIAN gives to a corporation entity, when he says that "What is owed to the corporation is not owed to the individual members, and what the corporation owes the individual members do not owe." 26 If BRISSAud's conjecture is right, this amalgamation of the two concepts was brought about by the application of the collective name to the group function, a composite entity, and then the easy transition from the composite entity to the unit entity of the juristic person. Sir GEORGE JeSSEL's dictum uttered in the latter part of the ninefeenth century shows the same semasiological process in operation. The reason why it did not produce the same amalgamation in the nineteenth century that had occurred in the sixteenth will be evident at a latter stage of this discussion.

The unit entity concept thus gets into the law of the middle ages on the Continent, not only in the Law Merchant but also in the general legal theory of the times and therefore appears in most of the modern Roman derivative systems. It should be remarked again, however, that this concept does not go back of mediaeval times. It has no warrant from classical Roman law, and a citation of the Law Merchant, "the mediaeval Roman law and the classical Roman law as precedents for the "entity" doctrine has only one unit value and not three. ${ }^{27}$-So far as precedents are concerned there is no warrant for the entity theory of partnership in the classical Roman law . and its existence in mediaeval law on the Continent seems to be due to a false analogy of the unit entity of the juristic person and the composite entity of the partnership.

THE ENTITY THEORY IN THE EARIY ENGLISH LAW.

Before the time of COKE, who was appointed Lord Chief Justice in the year 1606 , "the Law Merchant as a special law was administered in special courts for a special class of people ; ${ }^{28}$ namely,

$*$ Si quid universitati debetur, singulis non debetur; nec quod debet universitas singuli debent. Digest, 3. 4- 7. 1 .

$2 \pi$ This reduction of several precedents to one would be, of course, of little importance, if so much had not been made of the assumed cumulative value of the appearance of the concept in several places widely separated in time and space.

23 Select Iissays in Anglo-American Legal History, Vol. III, p. 9, quoted from Scrutton's General Survey of the History of the Law Merchant. Cf. also Vol. III, p. 43, from Burdick's, What is a Law Merchant? 
the merchants of the towns and fairs. The few cases that appear in the Year Books prior to this time deal with partnership and allied associative relations only incidentally. Most of them are cited under actions in account or in references to tenures.

During the seventeenth and eighteenth centuries there seems to be in the cases no suggestion of the entity theory of partnership. Indeed Professor Burdick in his article on SOME JUdICIAL, MYTHS, ${ }^{29}$ does not cite any authority where a partnership is spoken of as a distinct person earlier than the fourth decade of the nineteenth century. The common law courts of the seventeenth century did, however, have a great deal of difficulty in differentiating the passive right of a common holding (the tenure concept) from the associative active right exercised by partners (the firm concept), and by premature definition of the latter as identical with the former they fell into errors similar to those made in our time by identification of the composite entity of partnership with the unit entity of the juristic person.

The few cases in the Year Books which deal with partnership matters seem to indicate that as early as the fourteenth century there is a premonition of the "tenancy in partnership" as defined in the UNIFORM PARTNERSHIP ACT, ${ }^{30}$ the existence of which in English law is so vigorously denied as late as the middle of the nineteenth century in an American court. ${ }^{31}$ In STATHAM'S ABRIDGEMENT, (Accompte, 2I), we find the statement that, "If a man receive a certain sum of money from me to use in trade, to our common profit, I should have a special action of Account, etc."32 Sir John DAviEs, who writes in the middle of the seventeenth century, says that this is secundum Legem Mercatoriam, while "by the rule of the common law, if two men be jointly seized of other goods, the one shall not call the other to account for the same."33 In a case tried a few years after the one reported by SxATHAM, in an action

2022 Harv. I. Rev., 396.

U. P. A. Sec. 25 (I).

31 Blake v. Nutter ( $184 \pi$ ), 19 Me. I7. "There is no such tenure of lands known to the law as a co-partnership tenure. They must be held either in joint tenancy or co-tenancy." For an account of this form of tenure in modern law, Cf. Burdick, Partnership Realty, 9 Col. L. Rev., 2r3-216.

*2 Statham's Abridgement of the Law. 'Franslated by Klingelsmith, p. 7. This case is referred by Statham to ro Ed. III (r337), though the translator admits that the case has not been identified in the Year Book of that date. Irangdell in A Brief Survey o: Equity Jurisprudence, p. 96 says, "One of two co-partners never is accountable to the other," but Barbour says that this statement applies to the later not the earlier common law. See The History of Contract in Early English Equity, IV Oxford Studies in Social and Legal History, 14; where several cases of account between partners are cited from the Year Books of the fourteenth century.

33 Manuseript Tract on Impositions, published in 1656. See Burdick, op. cit., pp. 42 and 48 . 
of account against a bailiff of two, not merchants, Serjeant KIRTON argued that the executors of both ought to join. But the court, KNYVET, J., said "A chattel in possession is not like a chattel in action, for the latter cannot be severed, and his executors cannot join in the action with the other who survived."34 This case is cited at the beginning of the seventeenth century ${ }^{35}$ as an authority for the later well established doctrine, Jus accrescendi inter mercatores locum non habet. Davies, in the work above referred to, says that this non-survivorship of title among partners comes from the Law Merchant, while the right of survivorship between two joint tenants is a rule of the Common Law. It is plain, therefore, that when the common law courts of England take over the business of the courts merchant, at the beginning of the seventeenth century, the group holding of the common tenure is quite distinct from the group holding by partners, which includes not only a common tenure but also a group activity. It is also an accepted theory that the law of the tenure is Common Law, while the law of the tenure combined with the group activity is assumed to be derived from the Law Merchant, and there seems to be no attempt until the latter part of the seventeenth century to assimilate joint tenure to the holding by partners. In 1670 it was held ${ }^{38}$ that "if there are two partners and one of them die, the survivor shall be charged for the whole." In I683 it was said by the Lord Keeper in Chancery:" "if the farm had been taken jointly by them and proved a good bargain, there the survivor should have the benefit of it; but as to stock employed in way of trade, that should in no case survive "*** and the custom of merchants is extended to all traders to exclude survivorship." It thus appears that tenancy in partnership as distinct from joint tenancy is a well established institution in the English common law courts in the seventeenth century, though it is not yet given a name, and it is said by the courts that the rules governing it are borrowed from the Law Merchant.

A few years after this last decision, a case came before Lord Hou' $T$, in the King's Bench, ${ }^{38}$ in which $A$ and $B$ were co-partners, and $a$ judgment was against $A$, and all the goods both of $A$ and $B$ were taken in execution. It was held, "that the sheriff must seize

\footnotetext{
st Year Book, $38 \mathrm{Edw}$. III $(1365)$, fol. 7 , tit. Accompt. For the difficulties in the interpretation of this, compare Buckley v. Barber, 6 Exch. Rep. 166 and 177 (1851).

${ }^{35}$ Hammond v. Jethro, 2 B. \& G. 99 ( $\left.16 \mathrm{Ir}\right)$. The smaxim, jus accrescendi, ctc., appears to have been good law as early as the time of the publication- of the Iraws of Oleron. See Burdick, What is a Law Merchant? 2 Col. L. Rev., 484 .

3 Anonymous, I Mod. 45 (I670).

st Jefferey v. Small, I Vern. Chanc. 217 (1683).

* Heydon v. Heydon, I Salk. 392 (1693).
} 
all, because the moieties are undivided $* * *$ and sell a moiety thereof undivided, and the vendee will be tenant in common with the other partner." This is usually interpreted as meaning that "partners are co-owners of partnership property holding as joint tenants." 39 The fallacy involved in this decision was immediately recognized. Only six years later ${ }^{40}$ the old doctrine that in partnership the remedy alone survives was reiterated in the King's Bench, but the confusion caused by the decision in Heydon v. Heydon has persisted down to the present time.11 This again is the old familiar fallacy of premature definition and reasoning from a divided middle. Lord Hort is said by Bundrck in the article before cited ${ }^{42}$ to be "hostile to the innovations of Lombard Street." $\mathrm{He}$ refused to accept the definition of partnership that had been worked out in the Law Merchant, namely, that it is a joint holding of men who are also acting conjointly. He looked only at the tenure side and there was no tenure in English common law which fitted the situation except joint tenacy. He therefore implicitly defined partners as joint tenants. The rest follows inevitably. If $\mathrm{A}$ and $\mathrm{B}$ are joint tenants and the sheriff severs the jointure by seizing $A$ 's share and selling it to $\mathrm{C}$, then $\mathrm{C}$ and $\mathrm{B}$ become tenants in common. The trouble about this is that none of it is true. The major premise is faulty. Partners are not joint tenants. They are joint tenants plus, and any attempt to eliminate the plits is like saying that two equals three.

Nothing seems to be added to the doctrine of partnership entity nor to that of tenancy in partnership by the litigation of the eighteenth century. At the end of this century the law was practically where it had been left by the case of Martin v. Crump above cited, ${ }^{43}$ though the confusion caused by the anomalous decision of Heydon v. Heydon became steadily worse. It was due to the efforts of Lord MANSFIEID, Chief Justice of the King's Bench from 1756 to 1788 , that the Law Merchant was "received" into the English Common Law. During his long period of service he systematized the existing customs of merchants and embodied them in the decisions of his court. Unfortunately for our purpose, not many partnership cases came hefore him, and consequently we do not get his assistance in answering these difficult questions as to the essential nature of partnership.

39 Cf. 29 Harv. I. Rev. 163 , where Dean Lewis discusses the unsatisfactory character of the decision.

13 Martin v. Crump, 2 Salk. 444 (1699).

41 Cí. note to Dean Lewis's discussion, 1. c., note 39, supra.

42 See Select Essays in Anglo-American Legal History, Vol. III, p. 45.

${ }^{43}$ Cf. Note 40, supra. 
For a half-century after Lord MANSFIEID the courts seem to have paid more attention to the legal fiction of a partnership by operation of law independent of any agreement by the parties themselves than to questions regarding the nature of partnership. It may be observed in passing that the futile attempts to find a final test for the existence of this mythical institution, first suggesed in the case of Grace v. Smith, in 1775 , shows again the characteristic features of a mechanical jurisprudence in the striving for an authoritative definition to be used as a basis for deductive reasoning from a rule of law, rather than a resort to the more rational process of determination of a right from the position and reasonable expectations of the parties. ${ }^{44}$

\section{THE MODERN ENTITY THEORY OF PARTNERSHIP. ${ }^{45}$}

In his article on JUDICIAL, MYrns, before cited, ${ }^{46}$. Professor BuRDICK says that the American courts begin as early as I832 to talk about a partnership as a "person" 4 " or "as an artificial person or being, distinct from the individuals composing it.", 48 This doctrine does not seem to have got into the treatises on partnership of this period. STORY, in the first edition of his COMMENTARIES ON THE LAW OF PARTNERSHIP, published in I84r, does not mention it in his discussion of English partnerships, although he says that according to the law of Scotland "the firm constitutes a distinct person." The first edition of Parson's, TREATISE ON THE LAW OF PARTNERsHIP, published in 1867 , defines a "partnership as the combination by two or more persons of capital, etc." He does not speak of a

14 The whole course of litigation from Grace v. Smith, $2 \mathrm{Wm}$. BI. 998 (1775), through Waugh v. Carver, 2 Hen. Bl. 235 (1793), and Cox v. Hickman, 2 H. of L. 268 (1860), to Mollwo v. Ct. of Wards, I. R. 4 P. C. Ap. 419 (I872), and Beecher v. Bush, 45 Mich. I88 ( $188 \mathrm{I}$ ), shows, in the words of the court in the last mentioned case, "that in so far as the notion ever took hold of the judicial mind that the question of partnership or no partnership was to be settled by arbitrary tests it was erroneous and mischievous." 45 Mich. 188.

${ }_{15} \mathrm{An}$ independent collection of the cases has not been made from this point on The cases cited in the various controversial articles appearing in late years have been used. Among the articles thus used are The Firm as a Legal Persion, 57 Cent. Law Jour. 343, by William Hamilton Cowles (rg03); the several articles discussing The Uniform Partnership Act by Dean William Draper Lewis and Judson A. Crane in 24 Yale L. Jour. 61\%; 28 Harv. L. Rev. 762 , and 29 Harv. Law Rev., 192 and 291 (1915 and 1916); and the articles by Professor Burdick on Partnership Realty, 9 Col. L. Rev. 197 (1909), and' Some Judicial Myths, 22 Harv. L. Rev. 392 (1909); also the chapter on the Nature of Partnership, in Burdick, On Partnership.

${ }_{40} \mathrm{Cf}$. Note 29, supra. It should be said that Professor Burdick does not include the partnership entity in the category of judicial myths.

17 Warner v. Griswold, 8 Wend. (N. Y.) 665 (I832).

43 Curtis v. Hollingshead, 2 Green. ( 14 N. J. I.) 402, 410 (I832).

1) Story, On Partnership, Ist ed., p. III. It is noticeable that the form of this statement shows the complete assimilation of the firm name; $i$. e. the name of the group, with the juristic person. Cf. Note 24, supra. 
partnership as a person or as an entity, although he makes a sharp distinction between the partnership and the joint tenancy or tenancy in common, and says that the partnership is "neither of these common law tenures modified in certain ways." Do During the next decade the courts begin to refer to a partnership as a "distinct entity," "a distinct and palpable entity," ",52 a legal entity distinct and different from the persons who constitute its component parts." Finally the term is incorporated in the definiton in our standard text on partnership cited at the beginning of this paper. Professor BEALE says that the acceptance of the doctrine by American jurists has been brought about mainly by the commanding influence of Dean Ames.

In I905, Dean AMEs, as chairman of the committee appointed by the Commissioners on Uniform State Laws to codify the law of partnership, secured the consent of that body "to draw it on the lines of the mercantile theory of a partnership." "In accordance with these instructions Dean AMEs submitted to the committee a draft of a partnership act in which a partnership is defined as "a legal person formed by association." This is usually quoted as "Draft $A$ " in the subsequent revisions of the act. ${ }^{55}$ When the committee, after Dean AMIS's death in Igro, found that the difficulties in the way of codification on the legal person theory seemed insurmountable, they went back to the association theory and prepared a draft which after several revisions was finally given out as THE UNIFORM PARTINERSHIP ACT, ${ }^{\text {;B }}$ from which is taken the second definition quoted at the beginning of this paper. ${ }^{57}$ This Act had been adopted in Pennsylvania, Maryland and Wisconsin by the year 1916, and is before the legislatures of a number of the states, including Michigan, during the present session. ${ }^{57 \mathrm{a}}$

\footnotetext{
Parsons, Treatise on the $X_{\text {raw }}$ of Partnership Ist ed. (1867), p. 6 and p. 3 .

52 Robertson v. Corsett, 39 Mich. 784 (1878).

52 Walker v. Wait, 50 Vt. 676 ( 5878 ).

83 Henry v. Anderson, 77 Ind. 363 (188r).

st Report of Amer. Bar Assoc, (1905), 757.

is 29 Harv. L. Rev. 171 , note 19 . Cf. also p. 165 , note 9.

so $A$ full account of the labors of the committee, of which Dean William Draper Iewis was chairman, and Mr. James B. Lichtenberger, of the Philadelphia Bar, associate draftsman, is given in an article written by Dean Lewis in 29 Harv. I. Rev. 158, and following.

${ }^{87}$ After Dean Ames's death the committee, of which Dean Lewis was the chairman, asked the Conference of Commissioners on Uniform State Laws to be allowed to continue the work on revision without being bound by the resolution passed at the suggestion of Dean Ames in 1905, which was assumed to confine them to the entity theory. Report of Amer. Bar Assoc. (r910), 1044. The result of the labors of the committee acting under these new instructions is found in the Uniform Partnership Act of I9I4.

57a The Act was adopted by the Michigan House on February 6, 1917, and by the Senate on April 6, 1917 .
} 
We may now consider the various points at which the need has been felt for the entity doctrine to explain legal situations that called for some unifying principle. As a matter of fact we do deal with the "firm" as a something that is not the individual members themselves. The firm is debited and credited on the partnership books. "Admissions made by one partner in such circumstances as to be binding upon the firm are receivable in actions against the partnership; in such cases they are the admissions of the firm. and not of the individual partner only." "A bill of sale conveying personal property to a partnership by its firm name is valid *** a mortgage of personal property to a partnership should be upheld under like circumstances." 59 Although in all these cases the firm is recognized as something other than the individual members composing it, no one of them assumes the existence of a unit entity extrinsic to the individuals. We are in every case dealing with the composite entity or group, not with a juristic person. The entity is immanent, in the theological sense, not extrinsic to the indivduals as in the artificial person. It has been held in the English Court of Appeal ${ }^{80}$ that the infancy of a partner will not prevent an adjudication of bankruptcy against the firm though the infant cannot be made subject to the bankrupt laws in respect of any debt contracted by the firm of which he is a partner. It was ruled that the bankruptcy proceedings should have been against the firm other than the infant partner and that in the bankruptcy. proceedings the partnership assets were available for the firm creditors. BuRdick thinks this is a "virtual recognition of the firm as an entity distinct from its members." PoLLOCK is quite positive that by it there is "no recognition of the firm as an artificial person distinct from its members." "61 PoLLOCK is here talking of the unit entity of the juristic person while BuRDICK may be assumed to have in mind the composite entity of the partnership grouping.

In an acute and learned article on THE FIRM AS A LEGAI, PERsoN, ${ }^{62}$ with very full citations of the cases on the subject, the author, Mr. William Hamiston Cowles, applies the "doctrine of the personality of the firm as a test to a large and instructive class of cases dealing with the distribution of firm assets in liquidation." The typical case is that of partners $A, B$ and $C$ incurring a firm debt. The partnership lien, by virtue of which either partner may demand that the debt be paid out of firm assets, immediately at-

\footnotetext{
s Burdick, On Partnership, and ed., p. 92.

s9 Hendren v. Wing, 60 Ark. 563 (1895).

N Loveland and Christmas v. Beauchamp, ig App. Cases, 607 (I894).

a Burdick, On Partnership, 2nd ed., p. 96 and Note I.

c2 Cf. 57. Cent. Law Journ. 343-353 (1903).
} 
taches. The firm creditors' quasi-lien also becomes immediately effective, by which, in case of insolvency of the firm, they will have a preference on firm assets as against claims of individual creditors. If however all members of the firm have disposed of their interests before the estate comes under the control of the court, the question arises whether the quasi-lien still attaches to the firm assets. The courts are divided on this point. ${ }^{63} \mathrm{Mr}$. CowLEs follows the minority opinion, apparently on the theory that neither partner owns the firm assets as such but only his share in the residue after all claims on those assets are met, and therefore a partner can not defeat the quasi-lien by transferring such assets to a third party. He then concludes: "If no one partner has any interest in the firm assets themselves it necessarily follows that all of them have none. But this is just what systems based on the Roman law mean by saying that ownership is in the firm, an artificial person." 64 This conclusion does not necessarily follow. The equitable rule of distribution of the assets of an insolvent partnership applies not to the assets of an artificial person extraneous to the individual partners but to the assets of the group which have been set aside for the benefit of the group and its creditors by the contract of partnership itself. It would seem that the variation in the decisions of the courts on this point hinge on a much simpler question; namely, may a partner or all the partners by any manipulation of the partnership assets deprive a creditor of the benefit of the quasi-lien upon which he depended when he dealt with the firm? The apparent injustice of this has appealed to the New York court and those courts that side with it. On the other hand the courts that are in the majority might well ask, if the quasi-lien is not terminated when a partner retires from the partnership, when will it be terminated? It would apparently result that if any chattel were once involved in a partnership business, it would be subject to this hidden incumbrance at least until the end of the statutory period. ${ }^{65}$

Menagh v. Whitwell, 52 N. Y. I46 ( 1873 ), is a typical case which holds that the quasi-lien is still good. Stahl v. Osmer, 31 Ore. 199 (1897), holds to the contrary, and this court claims that it represents the great weight of authority.

et Op cit., p. 348.

65 Mr. Cowles's account of the confusion of a partner's interest with a tenancy in common or a joint tenancy seems not borne out by the sequence of cases. Lord Holt announced in 1693 [See Heydon v. Heydon, I Saik. 392] that the vendee of a partner's interest was "tenant in common with the other partner." The equitable rule of distribution was not established by Ex parte Crowder (1715). It existed at least in a qualified form as early as 1683 [See Lord Craven v. Knight, 2 Chan. R. 226], and at that time the tenancy in common and the tenancy in partnership had not been amalgamated. Cf. supra. 
Many instances are cited by Mr. JUdSON A. CRANE ${ }^{80}$ in which the courts have treated the firm as a person. "A bill bearing the name of two firms engaged in two distinct trades, is signed by two persons." the individuals. Each firm name is the collective name of Titius et socii, just as it was in the time of BARTOLUS, but this collective name has not merged with the juristic person in the nineteenth century as it did in the sixteenth. "J8 "Joint creditors of all the partners on obligations not arising out of partnership transactions cannot prove against the firm estate." 69 Because the joint debtors in the one case hold their estate in joint tenancy, while in the other they hold as tenants in partnership, whom the creditors of the firm have trusted. In England there is no distinction between firm debts and partners' joint debts, ${ }^{70}$ because the same group is trusted in either case. Again, "Two firms consisting in part of the same members are joined in an insolvency proceeding. A non-resident creditor who has proved against one is not barred thereby from later seeking to enforce a claim against the other."71 Here again there is no need for thinking of the two firms as juristic persons. They are simply different groupings of the same persons.

The cases in which the courts have treated a single firm doing business in two separate jurisdictions as two entities can be explained in a similar way. "Taylor and Cassily were a firm doing business in Cincinnati and New Orleans, Taylor managing the New Orleans house, Cassily the one in Cincinnati. A draft drawn in Cincinnati, by a creditor of the firm, on Taylor and Cassily, New Orleans, and accepted in Cincinnati by Cassily, was held to be drawn on a 'mercantile person' outside the jurisdiction of Ohio."r" The "mercantile person" was the collective name of the group doing business in Louisiana.

Whether or not the Bankruptcy Act of July I, 1898, determined that the partnership was an entity in the Bankruptcy Court has been a subject of spirited discussion almost from the date it was promulgated. Professor BuRDICK says, in Igog, that the general opinion of those engaged in teaching the subject of partnership at that time was that the Act did "give full effect to the partnership

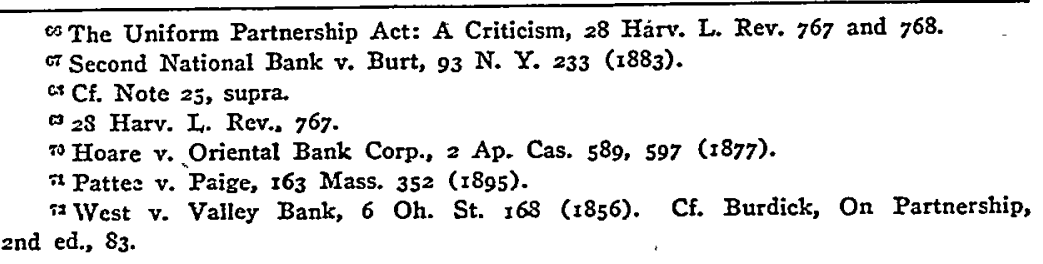


entity doctrine."73 In a note in the MICHIGAN LAW REVIEW, ${ }^{74}$ in I9I2, Mr. GEORGE E. HuMPhREYS reviews the litigation on this subject down to the date mentioned. He assumes that the Bankruptcy Act does recognize that a partnership is an entity and concludes that "a partnership will be uniformly declared to be an entity as an entity, for all purposes in bankruptcy." This note was written before the final decision was rendered in Francis v. McNeal. In the final decision of this case, ${ }^{75} \mathrm{Mr}$. Justice Hormes said that although the clauses of Sections I, 5a, and Ifa "taken together recognize the firm as an entity for certain purposes, the most important of which, after all, is the old rule as to the prior claim of partnership debts on partnership assets and that of individual debts upon the individual estate." nevertheless, "The firm remains at common law a group of men and will be dealt with as such in the ordinary courts. ***" Here again it would seem that the entity, if it exists within the meaning of the statute, is the composite entity of the group and not the unit entity of an extrinsic juristic person.

\section{QUID EST QUOD HAEC FABULA DOCET?}

At the end of the Pandects, ${ }^{\mathrm{T}}$ when the codifiers are wearied, and we may assume somewhat discouraged, with their task, they say, "Omnis definitio in jure civili periculosa est: parum est enim ut non subverti posset." It is usually acknowledged to be one of the great merits of the Corpus Juris Civilis that it has so far as possible avoided final rigid definition. In many places the Digest reads like a succession of syllabi of cases. Typical statements of facts, either actual or hypothetical, are laid down, followed by the decisions on those facts. In place of an abstract definition in the form of a rule of law we have the presentation of the facts in a typical case, and a statement of the rights of the parties in view of all the circumstances. With reference to this point the description of a partnership in THE UNIFORM PARTNERSHIP ACT has the advantage of the more abstract definition of a partnership as an entity. $A, B$ and $C$ do hold property together. They do unite in dealing with it and with other persons and groups. The statement then that "a partnership is an association of two or more persons to carry on as coowners a business for profit"77 simply states the fact that $A, B$ and $C$ have united their property, labor and skill for a joint effort. The

7322 Harv. I. Rev, 397.

74 Io Mich. I. Rev., 215.

75rancis v. McNeal, 228 U. S. 695 (1913).

76 Digest, 50. I7. 202.

7 U. P. A., Sec. 6, (1). 
statement that they are "tenants in partnership"78 again simply describes a typical situation. The parties are holding together and are acting as partners. The character of such action is then described in the next section under the incidents of such tenancy. ${ }^{78}$

The connotation of the idea of a firm is not the same as that of a juristic person. The firm concept, under which $A, B$ and $C$ hold jointly and act each for the group, differs in its very essence from the unit entity in which $A, B$ and $C$ are acting as agents for the persona, $\mathrm{X}$, extrinsic to the natural persons. The mediaeval law on the Continent brought the firm concept and the unit entity together by identifying the collective name with the artificial person, and in all the modern derivatives of the mediaeval Roman law of the Continent this amalgamation has persisted. The English Common Law in the seventeenth century had the idea of tenure highly developed and had also an elaborate scheme of group tenures in the forms of joint tenancy, coparcenary, and tenancy in common. But these were land tenures and were tenures simply, passive rights to hold, without active functions. During the earlier part of the seventeenth century, as we have seen above, when English courts dealt with active functions of the group in partnership, they borrowed from the mercantile law of the moribund staple and merchants' courts. But Lord Hori, in Heydon v. Heydon (1693), in an attempt to identify partnership with tenure, defined partners as joint tenants and the vendee of one partner's share as a tenant in common with the other partner, i. e., he attempted to amalgamate the tenure concept and the firm concept, above mentioned. Although the error was almost immediately recognized, it took more than a century of litigation to unscramble these two ideas. Indeed the law at the present time still shows some of the bad results of this forced union. But one of the effects of this struggle continued down through the eighteenth century was to get firmly fixed in the minds of common law courts and lawyers the idea that a partnership holding was sui generis, although a specific name for it does not seem to have been found until much later, and such a name seems to be necessary to keep an idea from coalescing with ore similar to it. ${ }^{80}$

In the nineteenth century, courts and jurists had to deal with the same problem as regards the firm concept and the unit entity which had confronted Lord HoLT in regard to the tenure concept and the firm concept. Modern English and American legalists had also a mediaeval precedent which had come down in Modern Roman Law

\footnotetext{
TU. P. A., Sec. 25. (I).

U. P. A., Sec. 25, (2), (a)-(e).

s Cf. 9 Col. I. Rev. 213 , Note 83.
} 
for identifying the group function of partnership with the juristic person. The amalgamation of the two was made the easier by the use of the word "entity" to describe the new concept, and by not recognizing that the unit entity of the juristic person and the composite entity of the partnership group, though similar in name, were quite distinct in their essence.

The confusion into which the courts fell by the partial adoption but hesitating acceptance of the entity doctrine may be shown by decisions in the New York court, which was the first to adopt it, according to Professor Burdick. ${ }^{81}$ In the case of Warner v. Griswold, ${ }^{81 \mathrm{a}}$, the court said, "They [partners] constitute but one person in the law." This court also said, in Menagh v. Whitzell, in IS73: "The well established rule which excludes creditors of the several partners from the partnership property until that has paid the debts of the partnership is derived from the acknowledgement that a partnership is a body by itself." But a few years later ${ }^{82}$ the same court said: "The firm is not recognized by lawyers as distinct from the members composing it." Mr. CowLEs in the article above cited, says the New York court "has said quite recently that it was only joking in its repeated declarations that the firm is a person." 83 Examples of similar wavering may be found in many other courts. The trouble seems to be that when the courts have needed a unifying principle they have assumed the unit entity of a juristic person to satisfy this need and then have found this definition is not in accord with actual facts in litigation. They have failed to recognize that an entity is, as Dean $L_{1}$ EWIS says, "phenomena grouped in the mind as possessing a common attribute not had by other phenomena"-and that the composite entity of the group satisfies this definition as well as does the unit entity of the juristic person.

Finally, as regards the precedents: The classical Roman law of partnership had common tenure well developed, in commmio, also the group function, a composite entity which included the passive holding by the group combined with a group activity, in the societas. There is, however, no hint of unit entity of the juristic person in the classic law of partnership. The mediaeval Law Merchant on the Continent by the fourteenth century had developed a composite entity and described it with the collective name, Titius et socii. By the sixteenth century the mediaeval lawyer had succeeded in amalgamating this composite entity with the unit entity of the juristic per-

5122 Harv. L. Rev. 393.

sia 8 Wend. (N. Y.) 666 (1832).

82 The Bank of Buffalo v. Thompson, I2I N. X. 280 (1890).

8 The Firm as a Legal Person, 57 Cent. Law Journ. 352 (1903).

\$ 29 Harv. I. Rev. I6I. 
son and was treating this partnership entity as identical with a corporate body. In the English Year Books the common tenure side of partnership was developing on the lines of common tenure of land. On the active side the partnership law borrowed from the law of merchants and established, apparently unconsciously, a "tenancy in partnership," though it did not give it a name. The courts kept these two concepts well separated, attributing the characteristics of land tenure to the passive, holding right in partnership, and indicating that the joint function, including the passive and active right in partnership, is a creature of the Law Merchant. During most of the seventeenth century the courts maintain a sharp distinction between joint tenure and partnership right, and the reaction after Lord Hor'T's unsuccessful attempt at bringing the two together under one definition, has made a sharply defined line of cleavage between these two concepts in our modern partnership law.

We thus begin the nineteenth century with no precedent for the entity theory derived from classic Roman law and with the precedent in mediaeval law resting on a false analogy. The attempt within the last half century to make the composite entity identical with the unit entity seems to have failed because in the language of one of our supreme courts: "A partnership cannot be considered as a person in contra-distinction to the persons composing it, simply because such is not its nature." 85

It is argued that this conclusion is reactionary because so many of our most advanced legal scholars during the last three decades have espoused the entity theory. Perhaps one answer to this might be that the Archon of the Progressive Party, Dean LEwIS, of the University of Pennsylvania, is the draftsman of the present Act. Furthermore he tells us $^{86}$ that all but one of the legal scholars, who agreed finally to the codification on the associative theory, had at one time believed that our law should adopt the legal person theory of partnership. All of those who were of this opinion changed their -minds because of the arguments advanced at their final conference held at Philadelphia in I9II. If the theory put forward in this

ss Stayton, C. T., in Wiggins v. Blackshear, 86 Tex. 670, (1894).

${ }_{29}$ Harv. L. Rev. 172. At the nieeting of the Committee on Commercial Law of the Conference of the Commissioners on Uniform State Laws, held at Philadelphia on Feb. 3-4, IgI1, the aggregate theory was supported by Professor Francis Burdick, Professor Floyd R. Mechem, Professor George D. Zohm, Professor William R. Vance, Pro fessor Aymar, and Mr. George Wharton Pepper and Judge Francis C. Lowell. Professor Samuel Williston is said to have advocated the entity theory at that meeting (see 23 Green Bag 220), but in an address before the Law Association of Philadelphia on Green Bag 220), but in an williston seems inclined to favor the adoption of The Uniform Partnership Act which is based on the aggregate theory. See 63 Univ. of Penn. Law Rev. 209. 
paper is correct, it is the entity doctrine that is the more reactionary, because on the precedent of a false analogy, it attempts to substitute a mechanical rule of law for a live working formula, by which our courts may decide cases in accordance with the circumstances and the reasonable expectations of the parties litigant.

Our legisiatures should adopt the tenancy in partnership and reject the partnership entity.

University of Michigan Law School.

JoSEPh H. DRAkE. 